\title{
Two new species of Indigofera (Fabaceae: Indigofereae) from south-western Queensland
}

\author{
Peter G. Wilson
}

\begin{abstract}
Wilson, Peter G. (National Herbarium of New South Wales, Royal Botanic Gardens, Sydney, NSW, 2000, Australia) 1994. Two new species of Indigofera (Fabaceae: Indigofereae) from south-western Queensland. Telopea 5(4): 631-635. Indigofera haematica and I. oxyrachis are described and illustrated. Both species have a fairly restricted distribution ecologically as well as geographically.
\end{abstract}

\section{Introduction}

The Australian species of Indigofera are being revised by the author. The two species described below are of limited distribution in the south-west of Queensland and were apparently not recorded in the recent vegetation survey of the area (Boyland 1984). They have so far been found in the Gregory North, Gregory South or Mitchell Districts, remote areas that are still poorly known botanically.

Floral measurements are based on material preserved in spirit or on reconstituted herbarium material.

1. Indigofera oxyrachis Peter G. Wilson, sp. nov.

I. leucotrichae maxime similis sed rachidibus foliorum spinescentibus, inflorescentiis multo brevioribus, fructibus subglabris differt.

TYPE: QueENSLAND: Mitchell: 'Budgerygar', 64 km SW of Yaraka, R.W. Johnson 3070, 11 Oct 1975; holo BRI.

Erect or spreading subshrub $0.25-0.4 \mathrm{~m}$ high; young stems white, occasionally flecked with brown, densely covered with appressed biramous hairs. Leaves 9-46 $\mathrm{mm}$ long, pinnate, mostly 3-7-foliolate; rachis \pm terete, appressed hairy but glabrescent, bearing a few orange-red glandular hairs between the leaflet pairs, the apex a sharp tip that projects abaxially beyond the point of attachment of the terminal leaflet; stipellae up to $1.3 \mathrm{~mm}$ long, narrowly obconical; leaflets obovate, emarginate with a small, recurved mucro, $4-10 \mathrm{~mm}$ long, $1.5-5 \mathrm{~mm}$ wide, white strigulose (hairs slightly denser below). Stipules narrowly obconical, straight or recurved, up to $1.8 \mathrm{~mm}$ long. Inflorescence a short axillary raceme, (4-)5-9(-15) $\mathrm{mm}$ long; peduncle $1-4.5 \mathrm{~mm}$ long; pedicels $1.5-4.5 \mathrm{~mm}$ long; bracts triangular, $0.8-1.5 \mathrm{~mm}$ long, deciduous. Calyx to 2 $\mathrm{mm}$ long, clothed with white to dark brown hairs; lobes unequal, shorter than or equal to the tube. Standard obovate, c. $6 \mathrm{~mm}$ long, c. $4.5 \mathrm{~mm}$ wide, deep pink, the outside bearing brown or golden-brown hairs, the inside glabrous, striate towards the base; wings oblong-spathulate, c. $6 \mathrm{~mm}$ long and $2 \mathrm{~mm}$ wide; keel $7 \mathrm{~mm}$ long, $2.1 \mathrm{~mm}$ wide, the distal end deep pink, glabrous; lateral pockets $0.4-0.5 \mathrm{~mm}$ long. Stamens 9+1; staminal tube 4-4.5 mm long. Ovary moderately to densely pubescent; style glabrous; stigma capitate. Pod cylindrical, (9-)15-35 $\mathrm{mm}$ long, 2-3.5 mm wide, with an acute apex, pale to dark brown, sparsely appressed-hairy; endocarp with pale orange-brown spots. Seeds cuboid, c.1.5 mm long, mostly 3-9 per fruit. Figure 1. 


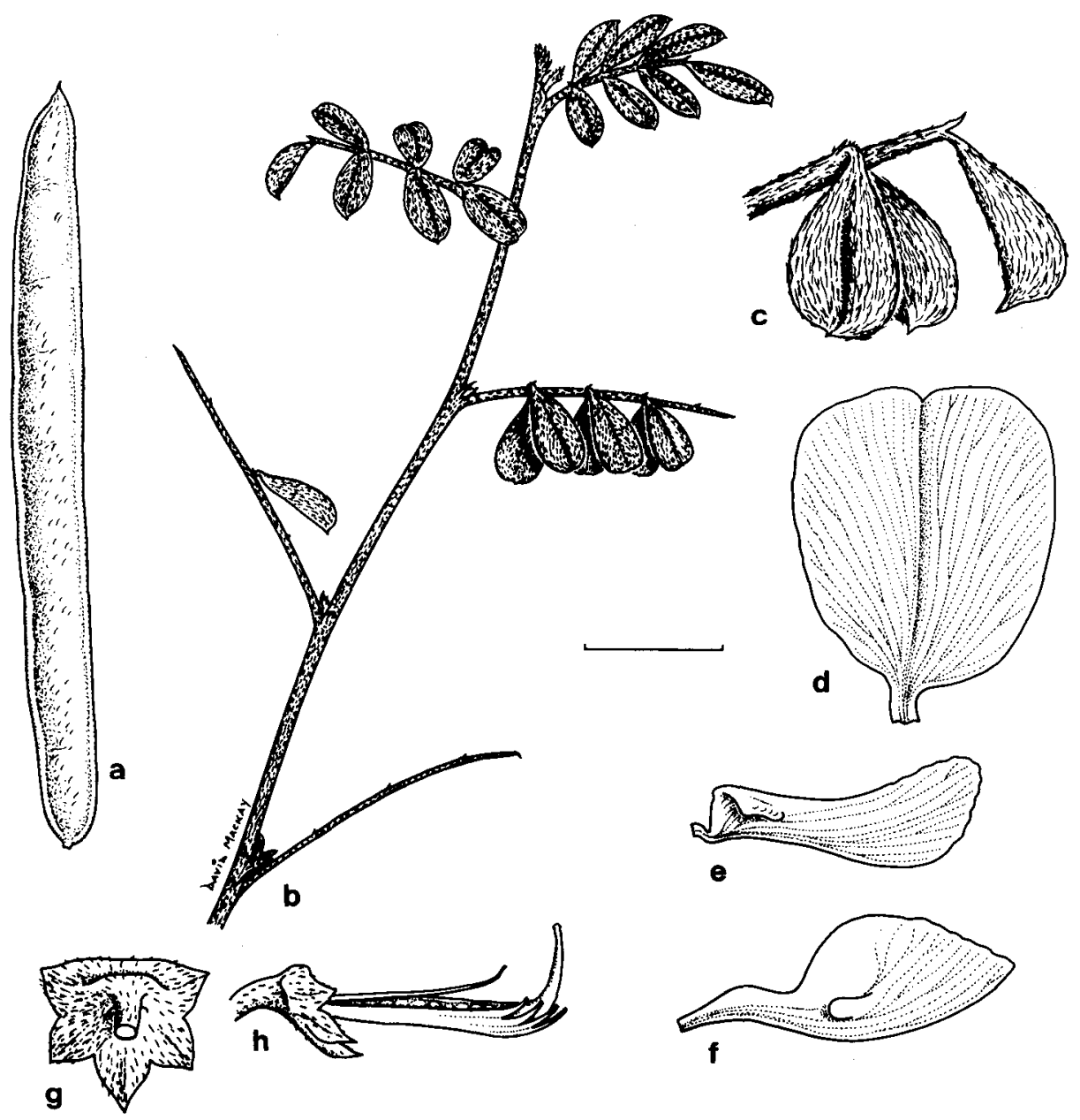

Figure 1. Indigofera oxyrachis. a, fruit; b, habit; c, leaf tip; $\mathbf{d}$, standard; $\mathbf{e}$, wing; $\mathbf{f}$, keel; g, adaxial view of calyx; $\mathbf{h}$, calyx, staminal tube and gynoecium. $(\mathrm{b}, \mathrm{c}, \mathrm{e}-\mathrm{h}$ from Wilson 372 \& Pickering; a,d from Johnson 3070). Scale bar for $a=6 \mathrm{~mm} ; b=12 \mathrm{~mm} ; \mathrm{c}=4 \mathrm{~mm}$; $\mathrm{d}-\mathrm{h}=3 \mathrm{~mm}$.

ETrmology: The epithet is derived from the Greek oxys, sharp, in reference to the spinescent leaf rachis.

FlOWERING PERIOD: Spring.

DistRIBUTION AND HABITAT: This species is known from only two areas about $190 \mathrm{~km}$ apart in south-western Queensland west of $144^{\circ} \mathrm{E}$. It is recorded from stony ground and along creek lines, with Acacia species. This species is unusual in that it is often found in the sandy beds of creeks rather than on hills or rocky outcrops as is the case for most shrubby indigenous species of Indigofera.

CONSERVATION STATUS: A coding of $3 \mathrm{~V}$ is suggested for this taxon on the basis of present knowledge. Although it is vulnerable to grazing by introduced stock, it does 
not seem to be killed by this and the geographic spread of the present records make it likely that further populations will be discovered.

Notes: The spinescent tip to the leaf rachis appears to have arisen as a modification of the terminal stipellae; if so, this is a unique development in Indigofera. Spinescent inflorescence axes are recorded by Gillett (1958: 50) for nine African species in four different subdivisions of the genus; these are said to be an adaptation to arid conditions. In $I$. oxyrachis the 'spine' is very weak and does not discourage grazing; most of the plants observed by the author along Hobson Gap Creek had been heavily grazed by stock.

AFFINITIES: The nearest related species is difficult to determine but must be among those species with stipellae. It is easily distinguished from all other species by the semi-persistent spinescent leaf rachis, and from other species in south-western Queensland by the shorter inflorescence, the less dense, appressed indumentum, and the almost glabrous fruit.

SPecimens examined: QueEnsland: Mitchell: Hobson Gap, $2.5 \mathrm{~km} \mathrm{~N}$ of first grid on 'Trinidad' 'Budgerygar' track, Wilson 372 \& Pickering, 19 Sep 1989 (NSW); Hobson Gap Creek, 7.7 km N of first grid, Wilson $373 \mathcal{E}$ Pickering, 20 Sep 1989 (NSW, BRI). Gregory South: 'Mt Howitt' station, 80 miles [c. $130 \mathrm{~km}$ ] W of Eromanga, Blake 11914, 3 July 1936 (BRI, CANB).

\section{Indigofera haematica Peter G. Wilson, sp. nov.}

$\mathrm{Ab}$ aliis speciebus australiensibus foliolis subteretibus, vexillo marronino facile distinguenda.

TYPE: QueENSLAND: Gregory South: $27.5 \mathrm{~km}$ from 'Cooma' turn-off on road to 'Plevna Downs', $26^{\circ} 35^{\prime} \mathrm{S} 142^{\circ} 45^{\prime} \mathrm{E}$, Peter G. Wilson $445 \mathcal{E}$ R. Pickering, 26 Sep 1989; holo NSW; iso BRI, K.

Erect, slender shrub to $0.4 \mathrm{~m}$ high; young stems ridged, hairs appressed, biramous. Leaves 15-75 mm long, pinnate, (5-)9-17-foliolate; petiole 4-17 mm long; rachis \pm terete, furrowed, appressed hairy, bearing groups of orange-red glandular hairs between the leaflet pairs; stipellae absent; leaflets narrow-oblong to subterete and grooved above, $1.5-12 \mathrm{~mm}$ long, $0.3-0.8 \mathrm{~mm}$ wide, glabrous or sparsely hairy; apex recurved, acute. Stipules narrow-triangular, straight or recurved, $0.6-1.8 \mathrm{~mm}$ long. Inflorescence an axillary raceme, $13-45 \mathrm{~mm}$ long; peduncle $5.5-19 \mathrm{~mm}$ long; pedicels 2-4.5 mm long, up to $6 \mathrm{~mm}$ long on mature fruit; bracts triangular, 0.7-1.5 long, tardily deciduous. Calyx 2.4-4.5 mm long, sparsely appressed-hairy, lobes shorter than or equal to the tube. Standard elliptical to obovate or orbicular, $5.8-11.5 \mathrm{~mm}$ long, $5.5-8.0 \mathrm{~mm}$ wide, maroon to blood-red, the outside bearing white or golden hairs, the inside glabrous, white towards the base; wings oblong to spathulate, 6.2-9.2 $\mathrm{mm}$ long, 1.5-2.8 mm wide, pink; keel $6.4-9.1 \mathrm{~mm}$ long, 2.2-3.3 mm wide, white tinged with pink, hairs sparse to moderately dense; lateral pockets $1.2-1.7 \mathrm{~mm}$ long. Stamens 9+1; staminal tube 4-7.3 mm long. Ovary glabrous; style glabrous; stigma capitate. Pod compressed-cylindrical, 25-33 mm long, 2-3 mm wide, with an acuminate apex, pale to dark brown, glabrous; endocarp with inconspicuous, very pale brown spots. Seeds cuboid to compressed-cylindrical 2-3 $\mathrm{mm}$ long, 5-8 per fruit. Figure 2.

ETYMOLOGX: The specific epithet is derived from the latinised Greek haematicus, bloodred, a reference to the colour of the standard.

FLOWERING PERIOD: Spring.

DISTRIBUTION AND HABITAT: This species is known from only three localities in southwestern Queensland, two in the vicinity of the Mayne River and one west of Eromanga, some $365 \mathrm{~km}$ apart. It is recorded from the dissected tops of residual 


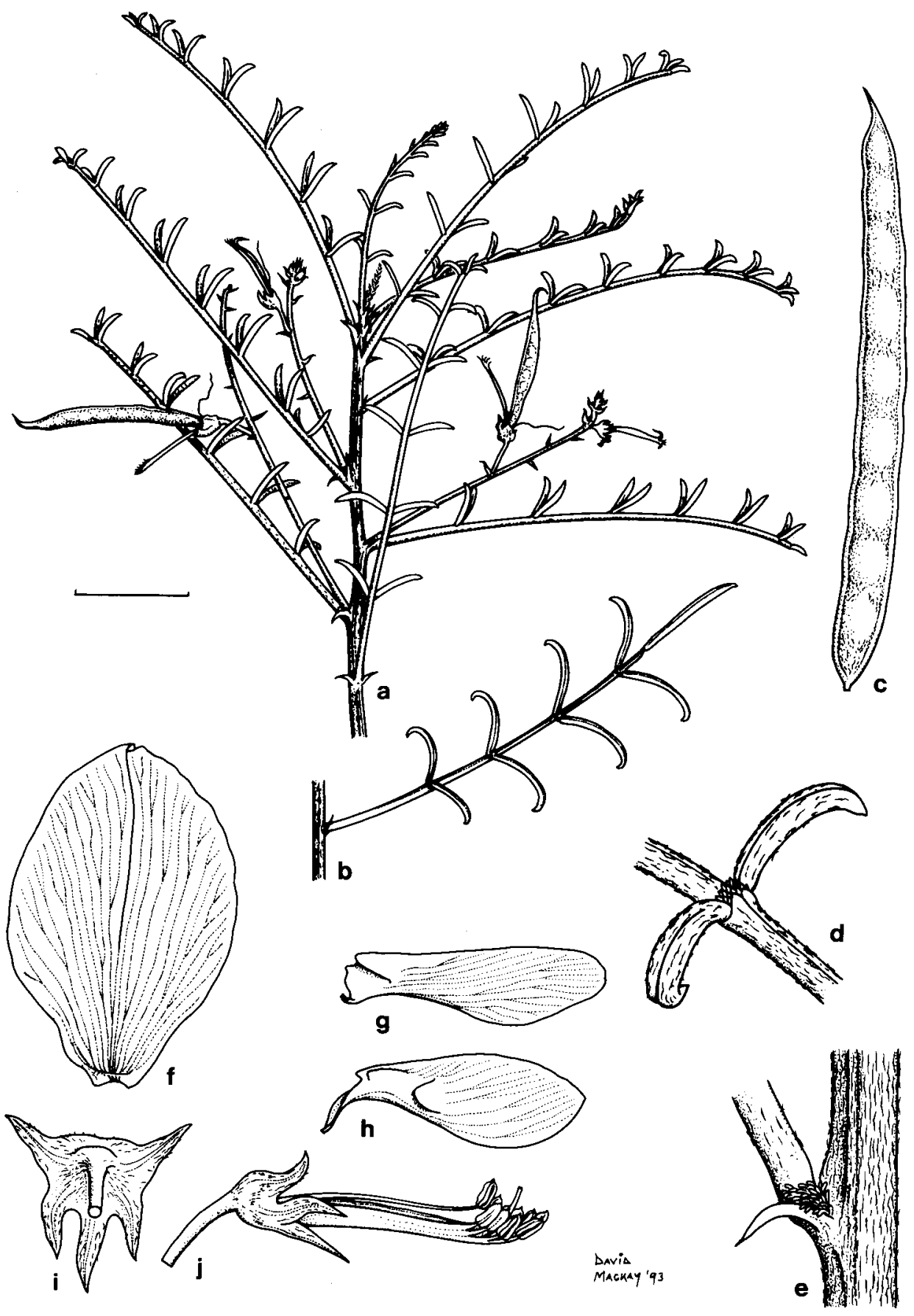

Figure 2. Indigofera haematica. $\mathbf{a}$, habit; $\mathbf{b}$, leaf; $\mathbf{c}$, fruit; $\mathbf{d}$, leaflet pair showing glandular hairs; e, stipule with glandular hairs; $\mathbf{f}$, standard; $\mathbf{g}$, wing; $\mathbf{h}$, keel; i, adaxial view of calyx; j, calyx, androecium and gynoecium. (a,d-e from Wilson 387 \& Pickering; b,c from Wilson $446 \mathcal{E}$ Pickering; $\mathrm{f}-\mathrm{j}$ from Wilson $445 \mathcal{E}$ Pickering). Scale bar for $\mathrm{a}, \mathrm{b}=8 \mathrm{~mm}$; $\mathrm{c}=6 \mathrm{~mm} ; \mathrm{d}, \mathrm{e}=1.5 \mathrm{~mm} ; \mathrm{f}-\mathrm{j}=4 \mathrm{~mm}$. 
plateaux where it is often found growing from crevices in bare rock. It is recorded as growing in association with Acacia stowardii, A. ensifolia, A. shirleyi, Eucalyptus thozetiana and Triodia spp.

CONSERVATION STATUS: A coding of $3 R$ is suggested for this taxon on the basis of present knowledge. The remoteness and the rocky nature of the collecting sites and the lack of evidence of grazing or any other pressure on the populations examined leads me to the conclusion that this taxon, although rare, should not be considered to be at risk. The very wide gap between the two areas in which collections have been made, and the occurrence of other, similar rocky plateau areas in the intervening region make it highly likely that further populations will be found.

AFFINITIES: This species is rather different from all other Australian Indigofera spp. in having narrow to subterete leaflets and flowers with a blood-red standard and pink keel and wings. It does not seem to be related to any other red-flowered species in Australia, except perhaps the undescribed red-flowered taxon previously erroneously referred to I. brevidens It is probably closest to I. australis and its allies, with which it shares the characters short calyx teeth, groups of glandular hairs between the pairs of leaflets and in the axils of the stipules, and sparsely hairy to glabrous fruits.

SPECIMENS FXAMINED: QueENSLAND: Gregory North: $22 \mathrm{~km} \mathrm{~W}$ of Vergemont Homestead, Neldner 2349 \& Stanley, Apr 1986 (BRI); 5-6 km N of Mayne River, Tonkoro-Winton road, Purdie 1523, 6 June 1979 (BRI); $5.6 \mathrm{~km}$ N of Mayne River, Wilson 387 \& Pickering, 21 Sep 1989 (NSW, AD, BRI, CANB, K, MO). Gregory South: $27.5 \mathrm{~km}$ from 'Cooma' turn-off on road to 'Plevna Downs', Wilson $446 \mathcal{E}$ Pickering, 26 Sep 1989 (NSW, BRI, CANB, K).

\section{Acknowledgements}

Many thanks to Ross Rowe for his technical assistance. My thanks also to Robyn Pickering for assistance with field work and to David Mackay for the illustration. This work was partly funded by an Australian Biological Resources Study grant.

\section{References}

Boyland, D.E. (1984) Vegetation Survey of Queensland. South-western Queensland. Queensland Botany Bull. 4.

Gillett, J.B. (1958) Indigofera (Microcharis) in tropical Africa with the related genera Cyamopsis and Rhynchotropis. Kew Bull., Additional Series 1. 